\title{
Pengembangan Potensi Wisata Igir Wringin di Desa Panusupan Sebagai Produk Wisata Berbasis Perdesaan
}

\author{
Kanita Khoirun Nisa ${ }^{1}$, Michael Jeffri Sinabutar ${ }^{2}$, Muhammad Alhada Fuadilah Habib ${ }^{3}$ \\ ${ }^{1}$ Jurusan Sosiologi UIN Sunan Kalijaga Yogyakarta \\ Email : kanita.nisa@uin-suka.ac.id \\ ${ }^{2}$ Jurusan Sosiologi Universitas Bangka Belitung \\ Email : jeffrisinabutar@gmail.com \\ ${ }^{3}$ Jurusan Manajemen Bisnis Syariah UIN Sayyid Ali Rahmatullah Tulungagung \\ Email : habibhada@gmail.com
}

\begin{abstract}
This study aims to explore the development of tourism potential of Igir Wringin in Panusupan Village. The method used is a qualitative method with a descriptive approach. This study explores how the youth of the community began to explore tourism potential, then developed it into a DTW (Tourism Attraction) which then became rural tourism. The results showed that the potential of Panusupan Village was developed into rural tourism. The development of tourist destinations begins with mapping the DTW (tourist attraction) of the Panusupan tourist village. The developed rural-based tourism is igir wringin tourism. The attraction and accessibility is easy to reach and through the hills. However, there are obstacles in the development, namely the community around the tourism object has not been directly involved. Only young people are actively developing tourism.
\end{abstract}

Keywords : Development; Tourism; Potential; Igir Wringin; Rura

$\overline{\text { Abstrak. Penelitian ini bertujuan mengeksplorasi pengembangan potensi wisata Igir Wringin di Desa Panusupan. }}$ Metode yang digunakan adalah metode kualitatif dengan pendekatan deskriptif. Penelitian ini mengeksplorasi bagaimana awal mula penggalian potensi wisata oleh para pemuda komunitas, kemudian dikembangkan menjadi DTW (Daya Tarik Wisata) yang selanjutnya menjadi pariwisata perdesaan. Hasil penelitian menunjukan bahwa potensi yang dimiliki Desa Panusupan dikembangkan menjadi pariwisata perdesaan. Pengembangan destinasi wisata dimulai dengan pemetaan DTW (daya tarik wisata) desa wisata Panusupan. Wisata yang dikembangkan berbasis perdesaan tersebut adalah wisata igir wringin. Daya tarik dan aksesbilitas yang mudah dijangkau dan melewati perbukitan. Namun, disana ada kendala dalam pengembangan yaitu masyarakat sekitar obyek wisata belum terlibat secara langsung. Hanya para pemuda yang aktif mengembangkan wisata.

Kata Kunci : Pengembangan; Potensi Wisata; Igir Wringin; Pedesaan

\section{PENDAHULUAN}

Pembicaraan mengenai pariwisata perdesaan tidak dapat dipisahkan dari pengertian wisata itu sendiri. Menurut Undang-Undang RI Nomor 10 tahun 2009 tentang Kepariwisataan, wisata adalah kegiatan perjalanan yang dilakukan oleh seseorang atau sekelompok orang dengan mengunjungi tempat tertentu untuk tujuan rekreasi, pengembangan pribadi atau mempelajari keunikan daya tarik wisata yang dikunjungi dalam jangka waktu sementara. Banyak konsep atau definisi Pariwisata Perdesaan. Pengertian tersebut berdasarkan pada kesediaan fasilitas, kegiatan yang dilakukan ataupun berdasarkan pada budaya dan tradisi yang ada di desa tersebut (Hadiwijoyo, 2012).

Pariwisata perdesaan merupakan suatu bentuk pariwisata yang bertumpu pada obyek dan daya tarik berupa kehidupan desa yang memiliki karakteristik khusus dalam masyarakatnya, panorama alamnya, maupun budayanya, sehingga mempunyai peluang untuk dijadikan komoditi bagi wisatawan. Kehidupan desa sebagai tujuan wisata adalah desa sebagai obyek sekaligus subyek dari 
kepariwisataan. Sebagai sebuah obyek artinya bahwa kehidupan perdesaan merupakan tujuan bagi kegiatan wisata, sedangkan sebagai subyek artinya bahwa desa dengan segala aktivitas sosial budayanya merupakan penyelenggara sendiri dari berbagai aktivitas kepariwisataan, dan apa yang dihasilkan dari kegiatan tersebut akan dapat dinikmati oleh masyarakat secara langsung. Peran aktif masyarakat sangat menentukan dalam kegiatan pariwisata perdesaan (Hadiwijoyo, 2012).

Potensi wisata menurut Mariotti dalam (Yoeti, 1983), adalah segala sesuatu yang terdapat di daerah tujuan wisata, dan merupakan daya tarik agar orang-orang mau datang dan berkunjung ke tempat tersebut. Potensi wisata dikaitkan dengan geografi wisata. Geografi pariwisata merupakan sebuah sistem karena memiliki berbagai undus yang menunjang kepariwisataan yang memiliki fungsi masing-masing dan menunjang antar unsur. Sistem kepariwisataan terdiri atas beberapa unsur, diantaranya adalah interaksi antara daerah tujuan wisata (DTW) dengan wisatawan dan ketersediaan sarana penunjang kepariwisataan (Hadiwijoyo, 2012).

Kabupaten Purbalingga mempunyai beragam produk wisata, baik obyek wisata maupun fasilitas sebagai penunjang. Ada suatu Desa yang terletak di perbatasan Kabupaten Purbalingga dan Kabupaten Pemalang, yaitu Desa Panusupan. Desa Panusupan merupakan sebuah desa wisata yang mengembangkan beberapa potensi wisata. Namun, disini penulis ingin memfokuskan pada satu destinasi saja. Destinasi tersebut bernama Igir Wringin. Istilah lain sebutan untuk Igir Wringin adalah rumah pohon. Rumah pohon merupakan jenis wisata tracking. Wisata ini biasanya disenangi oleh kaum muda mudi dan remaja. Dalam pengelolaannya wisata Igir Wringin dikelola oleh para pemuda. Namun kenyataannya hanya beberapa saja para pemuda yang terlibat untuk mengembangkan potensi wisata.

Penggabungan kedua konsep penting antara pengembangan dengan masyarakat sesungguhnya telah memberi makna berarti terhadap keberlangsungan proses atau dapat berupa metode yang memungkinkan orang mampu meningkatkan kualitas hidup dan memperkuat pengaruh terhadap ragam faktor penentu kehidupan yang dijalani (AMA, 1993). Makna pengembangan masyarakat dapat berupa pelayanan yang menggunakan berbagai pendekatan dengan nuansa pemberdayaan (empowerment) secara serius memperhatikan keragaman pengguna dan pemberi pelayanan (Suharto, 1997).

Pengembangan masyarakat yang berorientasi pemberdayaan mempunyai dua kecenderungan yang perlu diperhatikan dengan seksama dengan fokus perhatian terletak eksistensi masyarakat. Kedua, kecenderungan yang dimaksud adalah kecenderungan primer dan sekunder. Kecenderungan primer menunjukan bahwa proses pengembangan masyarakat mengutamakan pengalihan atau pemberian sebagian kekuasaan, kekuatan dan kemampuan kepada warga yang membutuhkan agar lebih bisa mandiri, produktif dan kreatif dalam menyelesaikan berbagai permasalahan dan kebutuhan. Kecenderungan ini tepat bila diterapkan pada masyarakat yang telah mempunyai kesadaran, kesiapan, kemauan, kebutuhan dan dukungan aktif berpartisipasi dalam setiap kegiatan pengembangan masyarakat yang direncanakan. Jika kondisi masyarakat belum siap maka pencapaian tujuan pengembangan masyarakat dengan kecenderungan primer akan sulit terlaksana (Dumasari, 2014). Pengembangan masyarakat dengan kecenderungan sekunder diarahkan untuk mencapai kondisi kehidupan yang lebih baik melalui proses dialog. Kecenderungan sekunder perlu disesuaikan dengan tingkat kemampuan masyarakat dalam memanfaatkan sekaligus mengontrol alokasi fungsi sumber daya yang tersedia untuk dapat menyelesaikan permasalahan dan kebutuhan.

Salah satu stakeholder pariwisata yang sangat mempunyai peran adalah wisatawan. Wisatawan adalah seseorang yang melakukan perjalanan wisata. Menurut Pitana (2005), Dalam melakukan perjalanan wisata ataupun penetapan untuk melakukan kegiatan wisata seorang wisatawan banyak dipengaruhi oleh berbagai macam hal, baik itu secara internal maupun eksternal. Perjalanan wisata dilakukan oleh manusia untuk memenuhi kebutuhannya dalam mencari suatu pengalaman baru yang belum pernah mereka dapatkan sebelumnya. Faktor-faktor yang mempengaruhi seseorang untuk melakukan perjalanan wisata ini menjadi hal yang sangat menarik untuk dijadikan arahan dalam pengembangan daya tarik wisata (ODTW). 
Motif atau faktor yang mempengaruhi para wisatawan dapat dijadikan acuan untuk para pelaku pariwisata mulai pemerintah, penyedia jasa wisata, pengelola tempat wisata dalam menentukan kebijakan-kebijakan maupun keputusan yang sesuai dengan keinginan dan kebutuhan dari wisatawan itu sendiri. Beberapa pendekatan yang dapat dilakukan yaitu melalui pendekatan market driven maupun product driven.

Menurut Mill dan Morrison (1985), didalam sistem kepariwisataan, terdapat dua unsur pokok yang menentukan dalam pengembangan pariwisata. Kedua unsure tersebut adalah Daya Tarik Destinasi dan Pelayanan. Kedua unsur tersebut merupakan inti dari kegiatan pariwisata yang mendorong bagi seseorang (calon wisatawan) untuk melakukan kegiatan wisata. Daya tarik destinasi dan kualitas pelayanan yang diberikan oleh para pelaku industry wisata kepada wisatawan di suatu destinasi wisata tersebut diatas akan berpengaruh terhadap kegiatan wisata yang dilakukannya, hal ini tentunya berkaitan langsung dengan minat kunjungan kembali wisatawan tersebut.

Penelitian oleh Anggit Kurnia (2020) tentang pengembangan desa wisata berbasis pemberdayaan di desa wisata Kaki Langit Padukuhan Mangunan. Hasil penelitian menunjukan bahwa pengembangan desa wisata yang melibatkan masyarakat sekitar desa wisata padukuhan Mangunan jauh lebih baik dari sebelumnya. Mayoritas masyarakat yang dulunya hanya mengandalkan sektor pertanian dan pekerjaan sampingan yang tidak menentu, melalui desa wisata di Mangunan mereka dapat berperan aktif memanfaatkan potensi lain yang dimiliki alhasil mendapat pendapatan baru. Selain itu, masyarakat juga membuka kesempatan kerja baru.

Penelitian oleh Riska (2021) tentang Pengembangan Desa Wisata Berbasis Komoditas Unggul di Payo. Hasil penelitian menunjukan bahwa pengembangan agrowisata Payo didukung oleh Pemerintah Daerah dan Stakeholder. Namun penerapan tekhnologi pertanian masih tradisional, sehingga diperlukan dukungan inovasi tekhnologi Balitbangtan dalam pengembangan agrowisata solok. Keterlibatan Balitbangtan dalam upaya tersebut dapat diawali dengan pembuatan granddesain dukungan inovasi tekhnologi Balitbangtan dalam kawasan Agrowisata Payo.

Penelitian oleh Wayan Adi (2021) tentang Pengembangan Desa Muntigunung sebagai Desa Wisata Baru di Kecamatan Kubu, Kabupaten Karangasem. Hasil penelitian menunjukan bahwa dalam strategi pengembangan desa wisata Muntigunung terdiri dari 4 strategi yang diidentifikasi berdasarkan faktor eksternal dan internal berupa strategi SO, strategi WO, strategi ST dan strategi WT. Desa Muntigunung yang notabene baru ditetapkan sebagai desa wisata di Kabupaten Karangasem oleh Pemerintah memiliki potensi-potensi wisata yang layak untuk dikunjungi. Ada potensi wisata berdasarkan attraction, accessibility, amenitas dan anciliary.

Akomodasi merupakan tempat tinggal sementara di tempat atau tujuan yang akan dikunjungi, yaitu penginapan, hotel, losmen, dan lain-lain. Atraksi wisata, yaitu sesuatu yang telah dipersiapkan terlebih dahulu untuk dilihat dan dinikmati oleh wisatawan seperti tari-tarian, nyanyi-nyanyian, kesenian rakyat tradisional, upacara adat dan sebagainya. Sementara itu konsumsi adalah sarana yang dapat memberikan pelayanan makan dan minum sesuai selera masing-masing wisatawan. Informasi adalah sarana untuk memberi pelayanan informasi tentang beberapa hal yang ingin diketahui wisatawan. Adapun yang dimaksud transportasi adalah sarana yang akan membawa wisatawan dari dan ke daerah tujuan wisata yang ingin diketahui (Suryadana, 2013).

\section{METODE PENELITIAN}

Penelitian ini bertujuan untuk mengidentifikasi potensi wisata di Desa Panusupan yang dikembangan oleh para pemuda yang tergabung dalam suatu komunitas. Penelitian ini merupakan penelitian deskriptif dengan menggunakan metode kualitatif. Data penelitian mengenai potensi wisata dan masyarakat yang mengembangkan potensi tersebut dikumpulkan melalui observasi lapangan, wawancara mendalam dan diskusi dengan kelompok di dalam komunitas tersebut. Tekhnik pengumpulan data melalui data primer dan sekunder. Teknik pengolahan data dengan cara menggunakan observasi, wawancara dan study literatur. 


\section{HASIL PENELITIAN DAN PEMBAHASAN}

Pada bagian hasil dan pembahasan dijelaskan mengenai berbagai potensi pariwisata perdesaan yang ada di Desa Panusupan. Potensi tersebut dikemas oleh masyarakat menjadi suatu produk wisata yang diminati oleh masyarakat. Selain daya tarik wisata, dalam mengelola pariwisata perdesaan juga dilengkapi dengan aksesbilitas dan fasilitas. Aksesbilitas bertujuan agar para wisatawan dapat dengan mudah menuju ke lokasi wisata. Sedangkan fasilitas bertujuan agar wisatawan dapat dengan enjoy dalam menikmati di tempat wisata.

Desa Panusupan memiliki keindahan alam yang sangat indah. Desa Panusupan banyak sekali memiliki potensi alam yang dikelola baik oleh pemuda dan masyarakat setempat. Desa Panusupan disahkan menjadi desa wisata pada tahun 2009. Pada saat itu juga dibentuk sebuah organisasi lokal yaitu kelompok sadar wisata yang dinamakan Pokdarwis Ardi Mandala Giri, yang disahkan oleh Dinbudparpora Purbalingga. Keaktifan Pokdarwis dimulai pada tahun 2014. Pengembangan destinasi wisata dimulai dengan pemetaan DTW (daya tarik wisata) desa wisata Panusupan. Adapun DTW desa Panusupan dibagi menjadi 3 yaitu DTW 1, DTW 2 dan DTW 3. DTW 1 terletak di Kadus II yaitu dusun Tipar.

Daya tarik wisata pada dusun tersebut yakni adanya kampong wisata Tipar yang meliputi Jembatan Cinta, Edukasi Pertanian, Agro wisata dan organik. Sedangkan untuk DTW 2 terletak di kadus III yaitu dusun Bojongsana. Daya tarik wisata pada dusun Bojongsana meliputi wisata alam adventure yakni Puncak Batur dan Susur Kali, Rumah Pohon Igir Wringin, Taman Puncak Simbarjaya. Sedangkan untuk DTW 3 terletak di kadus I, baik dusun Panusupan maupun dusun Karanggedang memiliki daya tarik wisata. Adapun daya tarik wisata tersebut dibagi menjadi dua, yaitu pertama daya tarik wisata Religi dan Seni Budaya yang meliputi Patilasan Ardi Lawet, Edukasi Seni Tradisional, Edukasi Purbakala, dan Home Industri. Kedua, wisata Keluarga meliputi Wanatirta Outbound Area, Puncak Sendaren, Curug Wanatirta.

\section{a. Maping Potensi}

Desa wisata Panusupan terdiri dari empat kadus, Kadus I yang meliputi dusun Panusupan dan dusun Karanggedang, Kadus II yang meliputi dusun Candi an dusun Tipar, kadus III yang meliputi dusun Bojongsana dan dusun Ragamukti, kadus empat yang meliputi dusun Batur dan dusun Pagelaran. Kepengurusan wisata di desa Panusupan yaitu berada dibawah kepengurusan Pokdarwis Ardi Mandala Giri. Para anggota pokdarwis bekerja dengan cara merancang program kerja selama 4 bulan. Rancangan program yang telah dibuat tersebut adalah:

Bulan pertama, Maping Potensi. Adapun maping dan pemetaan potensi wisata yang ada di desa yaitu: (1) berkaitan dengan jenis wisata apa yang akan dijual, (2) kepada siapa kita menjual, (3) fasilitas pendukung apa saja yang akan kita siapkan dan kita berikan kepada calon wisatawan. Bulan kedua, Sapta Pesona. Kegiatan yang dilakukan yaitu memberikan kesadaran sapta pesona kepada masyarakat, karena sapta pesona adalah inti dari kerja di bidang pariwisata: Aman, Tertib, Bersih, Sejuk, Indah, Ramah, Kenangan. Bulan Ketiga, Pelayanan dan Kesiapan Pemandu Wisata. Kegiatan ini guna memberikan tentang pelayanan prima dan menyiapkan pemandu wisata, yang mana pemandu wisata tersebut bertugas untuk a) bagaimana cara melayani tamu, b) bagaimana membuat tamu betah di desa wisata tersebut, c) bagaimana memandu tamu dengan baik. Bulan Keempat yaitu Pembuatan Paket wisata yang terdiri dari tiga kegiatan yaitu pertama melatih bagaimana cara membuat paket wisata dan cara menghitung harga pokok produksi dan untung/rugi, kedua cara membuat proposal yang menarik untuk konsumen, ketiga, cara membuat pamphlet atau brosur yang menarik calon wisatawan.

Wisata Igir Wringin di Panusupan Purbalingga Jawa Tengah adalah salah satu tempat wisata yang berada di Desa Panusupan, Kecamatan Rembang, Kabupaten Purbalingga, Jawa Tengah. Wisata Igir Wringin di Panusupan Purbalingga tersebut merupakan tempat wisata yang ramai dengan wisatawan pada hari biasa maupun hari liburan. Tempat ini sangat indah dan bisa memberikan sensasi yang berbeda dengan aktivitas kita sehari hari. 


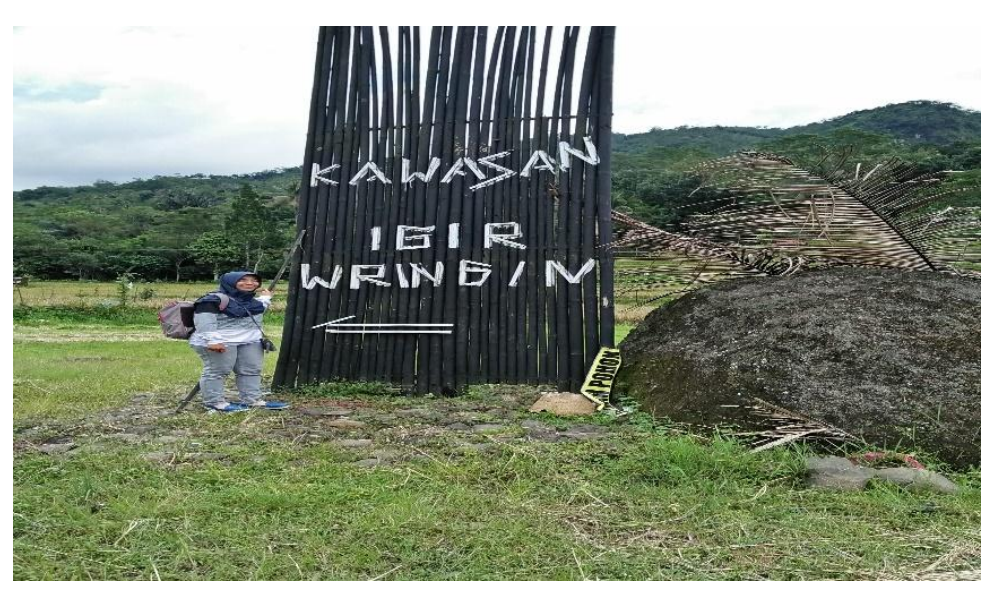

Gambar 1. Akses menuju kawasan igir wringin

Wisata Igir Wringin di Panusupan Purbalingga Jawa Tengah memiliki pesona keindahan yang sangat menarik untuk dikunjungi. ika anda berada di kota Purbalingga tidak mengunjungi Wisata Igir Wringin di Panusupan Purbalingga Jawa Tengah yang mempunyai keindahan yang tiada duanya tersebut. Keindahan Daya Tarik Wisata Asam Jokowi terutama terletak pada keindahan pemandangan alamnya dan juga kreatifitas warga setempat. Wisatawan dapat mengabadikan momen di tempat tersebut lalu lanjut untuk menikmati pemandangan alam yang disuguhkan oleh DTW Igir Wringin. Fasilitas wisata merupakan pelayanan pendukung yang dapat dimanfaatkan wisatawan dalam menawarkan mutu dan harga yang sesuai dengan kebutuhan wisatawan (Mill, 2020).

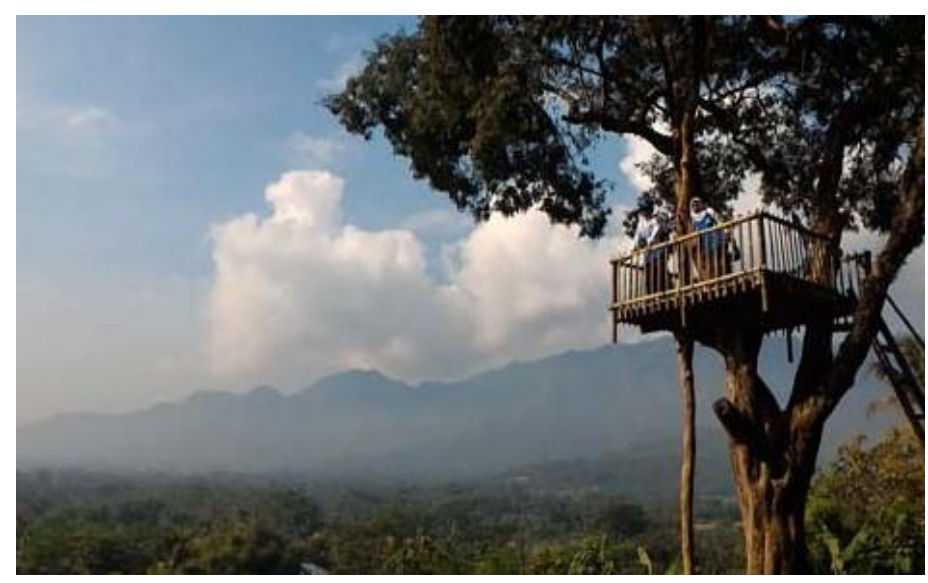

\section{Gambar 2: Igir Wringin dengan pemandangan panorama alam}

Destinasi wisata Igir Wringin merupakan daya tarik baru yang kepemilikan dan pengelolaannya dilakukan komunitas pemuda di Desa Panusupan. Terletak di lokasi yang berada diketinggian di bukit Gunung Ardilawet. Yang mana Gunung Ardilawet merupakan tempat pesarehan Syekh Jambu Karang, salah satu wali di Jawa yang berada di Purbalingga. Letaknya yang berada di bukit ketinggian membuat kunjungan wisatawan semakin hari semakin banyak. Hal ini karena dengan berwisata di alam, para pengunjung dapat merasakan ketenangan, rasa tentram sekaligus rekreasi. Wisatawan juga dapat melakukan kegiatankegiatan wisata seperti berfoto dan rekreasi di destinasi Igir Wringin. 


\section{b. Daya Tarik Wisata}

Wisata Igir Wringin di Panusupan merupakan tempat wisata yang sangat eksotis karena pesona keindahannya luar biasa. Penduduk lokal daerah Wisata Igir Wringin di Panusupan Purbalingga Jawa Tengah juga sangat ramah tamah terhadap wisatawan lokal maupun wisatawan asing. Kota Purbalingga juga terkenal akan Wisata Igir Wringin di Panusupan Purbalingga Jawa Tengah yang sangat menarik untuk dikunjungi. Wisata Igir Wringin di Panusupan Purbalingga Jawa Tengah merupakan bukit setinggi 640 meter di atas permukaan air laut (mdpl) ini mulai dibuka sebagai destinasi wisata. Wisata Igir Wringin di Panusupan Purbalingga memiliki tempatnya sejuk dan nyaman. Para pengunjung juga bisa berkemah sembari menikmati sunrise jika berkunjung ketempat ini. Wisata Igir Wringin di Panusupan Purbalingga banyak dikunjungi pemburu matahari terbit dari berbagai daerah. Setiap hari, pengunjung yang datang bisa mencapai 200 orang. Bahkan, di akhir pekan, bisa lebih dari 1.000 orang. Sesampai di pos pendakian, Anda akan dipungut biaya tiket Rp 5.000 per pengunjung dan $\mathrm{Rp} 2.000$ per motor.

Perjalanan pengunjung akan di pertemukan oleh Hamparan sawah yang tertata secara terasering menjadi pemandangan utama. Mendekati puncak bukit, jalanan terlihat curam. Bahkan, di beberapa titik, kemiringan mencapai 90 derajat. Pengunjung tidak perlu khawatir, sebab pengelola telah menyiapkan alat bantu berupa tali dan pegangan dari bambu untuk memudahkan pendaki menuju Igir Wringin. Selain itu wisata Igir Wringin juga dekat dengan pemukiman masyarakat setempat. Wisata Igir Wringin di Panusupan Purbalingga Jawa Tengah bisa dibilang sebuah wisata alam yang memiliki beberapa akan fasilitas dan pelayanan di antaranya sebagai berikut : Area Parkir kendaraan, Kamar mandi / MCK, Tempat Istirahat, Warung Makan.

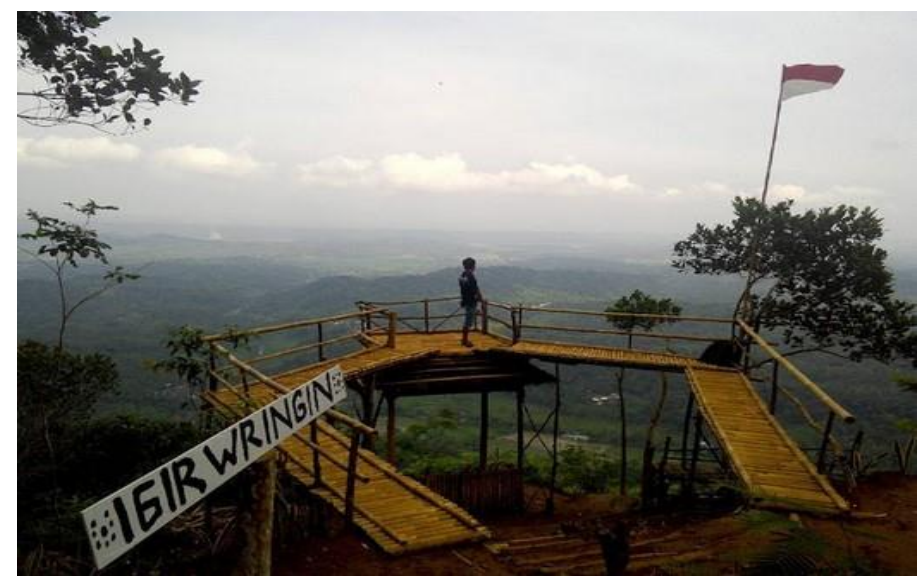

Gambar 3. Para Pemuda di Destinasi Wisata Igir Wringin menambah spot baru

Bagi wisatawan asal kota Purbalingga sudah tidak bingung lagi untuk mendatangi lokasi Wisata Igir Wringin di Panusupan Purbalingga Jawa Tengah. Akan tetapi bagaimana bagi wisatawan luar kota bahkan luar negeri, tentu mereka bingung dan takut kesasar. Tapi jangan khawatir bagi wisatawan luar kota Purbalingga saya mempunyai solusinya agar anda semua tidak kesasar. Sarana transportasi yang biasa digunakan oleh pengunjung untuk berwisata ke Wisata Igir Wringin di Panusupan Purbalingga Jawa Tengah dengan memakai kendaraan pribadi seperti : Mobil atau motor pribadi. Pengunjung bisa meminta panduan arah ke Wisata Igir Wringin di Panusupan Purbalingga Jawa Tengah di google maps yang terpasang di smartphone. Karena memakai kendaraan pribadi akan lebih menyenangkan dari pada memakai kendaraan umum. Akan tetapi jika anda memakai kendaraan umum seperti : bis umum atau angkutan lainnya juga bukan masalah besar, pasalnya anda bisa berhenti di Kecamatan Rembangan. Setelah itu melanjutkan dengan menggunakan ojek ataupun kendaraan pribadi anda menuju Desa Panusupan hingga sampai di lokasi Wisata Igir Wringin di Panusupan Purbalingga tersebut. 


\section{c. Minimnya Pelibatan Masyarakat}

Pada masyarakat sekitar obyek wisata Igir Wringin, mereka pernah diajak berdiskusi bahwa di sekitar area tempat tinggal mereka akan dibangun tempat wisata. Materi diskusi masih terbatas, sedangkan saat obyek wisata mulai dibuka masyarakat secara umum kurang terlibat. Hanya beberapa pemuda saja yang survive melakukan pembaharuan-pembaharuan spot wisata. Adanya aktivitas berjualan maupun bergadang juga hanya sedikit. Kemudian, yang membantu menjaga parkiran juga anak muda setempat. Masyarakat kurang terlibat dikarenakan pengetahuan mereka yang masih minim tentang pariwisata.

Agar terjadi proses "Handarbeni" (rasa memiliki) dari masyarakat, maka sebenarnya masyarakat selalu dilibatkan dalam pengelolaan areal tempat wisata. Pelibatan tersebut seharusnya mulai dari perencanaan yakni apapun yang ingin diprogramkan oleh pengelola tempat pariwisata didiskusikan dengan masyarakat. Harapannya masyarakat merasa memiliki program tersebut, dan pada gilirannya masyarakat akan membantu kelancaran program tersebut. Pada tahap pelaksanaan, masyarakat juga bisa dilibatkan sesuai porsinya. Keikutsertaan dalam perencanaan akan lebih mudah bagi masyarakat untuk ikut serta dalam melaksanakan program dari Dinas Pariwisata untuk mengelola areal pariwisata sehingga tetap terjaga kelestariannya. Aspek lain yang sering dilupakan dalam partisipasi adalah evaluasi.

Masyarakat sering tidak dilibatkan pada tahap evaluasi ini, sehingga apa yang dilaksanakan masyarakat sekitar obyek wisata tidak pernah diketahui masyarakat bagaimana kondisi sesungguhnya karena tidak dilibatkan dalam tahap evaluasi. Pada tahap pemanfaatan hasil untuk sementara masyarakat secara langsung mengaku ikut merasakan. Hal ini dapat dilihat pada pernyataan mereka bahwa semenjak adanya tempat wisata masyarakat merasakan adanya peningkatan ekonomi melalui ikut berjualan yang diperuntukan bagi wisatawan. Selain itu, desa mereka menjadi terkenal dan menjadi rame dibanding sebelumnya. Selama ini mereka tidak merasakan adanya budaya-budaya lokal yang hilang hanya saja memang diakui bahwa ada pengaruh luar yang diadopsi oleh masyarakat terutama mengenai pergaulan remaja yang semakin bebas (Demartoto, 2013).

\section{KESIMPULAN}

Berdasarkan hasil penelitian dan pembahasan diatas maka dapat ditarik kesimpulan bahwa sampai saat ini masyarakat sekitar mulai dilibatkan dalam pengembangan potensi wisata Igir Wringin di Desa Panusupan. Pariwisata perdesaan di Panusupan didukung oleh potensi panorama alam yang indah, masyarakat yang ramah serta daya tarik wisata senin dan budaya. Kelemahan dalam pengembangan wisata berbasis pedesaan di Desa Panusupan adalah kurangnya partisipasi masyarakat dalam ikut serta mengelolanya. Berdasarkan simpulan diatas, maka rekomendasi/saran yang tepat adalah mengembangkan kemitraan untuk mengembangkan pariwisata perdesaan, sehingga dukungan masyarakat maupun investor semakin besar. Peningkatan kualitas obyek wisata baik pelayanan, sarana maupun prasarana.

\section{DAFTAR PUSTAKA}

Damamik, Janianton. 2015. Membangun Pariwisata dari Bawah Catatan Penelitian terhadap Desa Wisata Penerima PNPM Mandiri Pariwisata. Yogyakarta: Gadjah Mada University Press

Demartoto, Argyo. 2013. Pembangunan Pariwisata Berbasis Masyarakat. Solo: UNS Press

Dumasari. 2014. Dinamika Pengembangan Masyarakat Partisipan. Purwokerto: UMP Press

Hadiwijoyo, Suryo Sakti. 2012. Perencanaan Pariwisata Perdesaan Berbasis Masyarakat (Sebuah Pendekatan Konsep). Yogyakarta: Graha Ilmu

https://www.google.com/search?q=potensi+wisata+adalah\&oq=potensi+wisata+\&aqs=chrome.1.69i 57j0i51219.4253j0j7\& sourceid=chrome\&ie=UTF-8

JUMPA Jurnal Magister Pariwisata Vol 5 No 1, 2020 
JUMPA Jurnal Magister Pariwisata Vol 7 No 2, Januari 2021

Jurnal Nasional Pariwisata Vol 5 No 3, Desember 2013

Jurnal Nasional Pariwisata Vol 8 No 1, April 2016

Suryadana, M Liga. 2013. Sosiologi Pariwisata Kajian Kepariwisataan dalam Paradigma IntegratifTransformatif menuju Wisata Spiritual. Bandung: Humaniora

Tonny, Nasdian. 2014. Pengembangan Masyarakat. Jakarta: Yayasan Pustaka Obor Indonesia

Zubaedi. 2016. Pengembangan Masyarakat Wacana dan Praktik. Jakarta: Prenadamedia Group 